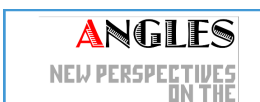
ANELOPHONE WORLD

\section{Angles}

New Perspectives on the Anglophone World

3 | 2016

Angles and limes

\title{
From a Stylistic Angle: Methodological Issues and Liminal Creativity
}

\section{Sandrine Sorlin}

\section{Q OpenEdition}

1 Journals

\section{Electronic version}

URL: https://journals.openedition.org/angles/1625

DOI: $10.4000 /$ angles. 1625

ISSN: 2274-2042

\section{Publisher}

Société des Anglicistes de l'Enseignement Supérieur

\section{Electronic reference}

Sandrine Sorlin, "From a Stylistic Angle: Methodological Issues and Liminal Creativity", Angles [Online], 3 | 2016, Online since 01 November 2016, connection on 08 June 2022. URL: http:// journals.openedition.org/angles/1625 ; DOI: https://doi.org/10.4000/angles.1625

This text was automatically generated on 8 June 2022.

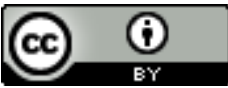

Angles est mise à disposition selon les termes de la Licence Creative Commons Attribution 4.0 International. 


\title{
From a Stylistic Angle: Methodological Issues and Liminal Creativity
}

\author{
Sandrine Sorlin
}

\section{Introduction}

1 If a "legitimate" field of study is a discipline that is represented in the competitive examinations for the national recruitment of teachers (CAPES/Agrégation), then it must be acknowledged that English stylistics has not found a legitimate place in the university syllabus of English departments in France. ${ }^{1}$ Yet at a national and international level, research in stylistics is well rooted. It is promoted by firmly established learned societies counting more and more members, such as the French Society of English Stylistics (Sociéte de Stylistique Anglaise, SSA) ${ }^{2}$ or the international Poetics and Linguistics Association (PALA) ${ }^{3}$ that publish articles in the field of stylistics through peer-reviewed journals (such as Études de Stylistique Anglaise and Language and Literature). From being a sub-discipline to linguistics, (international) stylistics has grown into a well-established, mature, coherent discipline in its own right whose field is well defined, as is shown by the recent publication of handbooks in prestigious British publishing houses. ${ }^{4}$ The dichotomy between scarce courses in stylistics and intense research activity in the French context is all the more paradoxical as stylistic approaches have proved beneficial for the study of English grammar in context and the practice of creative writing by non-English speakers. ${ }^{5}$

2 This paper aims at questioning the borders of stylistics. Academically, it suffers from being stuck in-between two well-established disciplines: linguistics and literature. By bringing linguistic tools to work out literary interpretations, stylistics can be perceived as muddling the academic waters. The field will first be apprehended from external angles: through an exercise in polyphony, I will try to give voice to how the more academically implanted disciplines typically construe stylistics. These external 
examples of criticism will be uncompromisingly acknowledged and answered in a defence of the inherent specificity of stylistics. Rather than being built on a dismissal of what is outside, stylistics prides itself on fuzzy and permeable borders that enable it to remain open to other disciplines. Its "give and take" capacity (see Sorlin 2014b) makes it a bridging discipline that can absorb other enriching fields of language study (e.g. Critical Discourse Analysis, Pragmatics or Conversation Analysis) and bring its own expertise to other disciplines. The very last section will give a short illustration of how stylistics can penetrate new disciplinary borders (e.g. film and TV series studies) with the hope of furthering research.

\section{The "legitimacy" of stylistics: Playing the devil's advocate}

3 Applying linguistic tools to the literary text, stylistics can be conceived as illegitimately playing in different fields. As this issue of Angles invites head-on clarification of the angles and limes that delimit a field of knowledge, I will put up a fake trial, highlighting the limits of stylistics from the points of view of its external limits: linguistics and literature. Successively an uncompromising literary critic and a linguist will be brought to the witness box on behalf of the prosecution in response to three charges each.

\subsection{Stylistics from the literary angle}

4 Here are the three main reproaches that the literary advocate could address to the delinquent stylistician stepping on her fieldwork:

1. Stylistics is too "text-bound" and does not seem to have gone beyond its formalist origins.

2. Stylistics offers overly mechanical linguistic text analysis.

3. Stylisticians are disrespectful of geographical areas and aesthetic periods.

In sticking to morphological, phonological, lexical, syntactic and semantic aspects of texts, stylistics has not taken the "cultural turn" and does not always sufficiently bring "form" in tune with cultural and historical contextualisation. Besides, stylistic analysis often comes close to theoretical linguistics, taking the form of arid hypotheses producing boring results. Quantitative corpus stylistics, for instance, in its rigorous counting of recurrent forms, transforms the literary text into disembodied statistics that cannot pay tribute to the subtlety of the work of art. Lastly, stylisticians claim to be language specialists of texts belonging to different times and cultures. They tend to overlook the dividing up of the literary field in terms of geopolitics (Scottish literature, Irish literature, post-colonial literature, etc.) or aesthetic movements (Victorian studies, modernism, postmodernism, etc.).

6 The difficult dialogue between literature and linguistics is no news. "Would I allow my sister to marry a linguist? It is a good question. And I suppose, if I am honest, I must admit that I would much prefer not to have a linguist in my family." ${ }^{\prime} \mathrm{Here}$ is, in the 1960s, how far the literary critic F.W. Bateson was ready to go to disqualify what he perceived as the useless and even detrimental role of the linguist in the study of his life work: literature. For him, the critic has a sensitivity to the literary material that can only be marred by the linguist's mechanical approach. He had in mind one of Roger Fowler's books, Essays on Style and Language (1966). For Bateson, there is altogether a 
natural incompatibility between the minds of the linguist and the literary critic: "If he is a natural grammarian he will divide and subdivide the verbal material; if he has been a literary critic, he will synthesise and amalgamate it" (Simpson 151). Only the sensitive and synthetic critic can be the guardian of the sanctity of the work of art. Descriptive linguistics fails to understand the humane values that inhabit the literary material. of course, this debate must be understood as being part of the liberal humanist tradition of the time that saw in the goodness of literature a possibility to be better oneself. But by expelling the stylistician from true literary criticism, Bateson concludes on the impossibility of dialogue: "let us agree to be different" (Simpson 152).

7 To be fair to my literary witness who has agreed to come to this mock trial, literary critics have long gone past some kind of sacralisation of creation. However, there remains the fact that, in their perception, the inherent ambiguity and uncertainty of the work of art is something that must be celebrated rather than formalised. But a cultural difference must be marked out here between the French literary scholars' and their British counterparts' attitude towards stylistics, especially given how hard a time British stylisticians had to make the literary critic understand what they were doing. Until very recently, stylisticians were on the defensive, as evidenced in Stockwell's following remark, which sounds like a claim of territory. For him a complete reversal of perceptions should actually be operated as stylistics is the discipline which has remained true to literary language while "literary studies" have drifted away from central language questions: "In fact it is the range of practices in literary scholarship in the institutional mainstream that is interdisciplinary: literary studies draws on history, or sociology, or economics, or politics, or philosophy, or creative art. Only stylistics directly faces the literary work on its own terms" (Stockwell and Whiteley 607). He goes as far as saying that literature should be construed as a branch of applied linguistics rather than stylistics be confined to the application of linguistics on the literary text: "It strikes me as odd now that we used to think of stylistics as the application of the discipline of linguistics to the separate field of literary studies: since literature is fundamentally a matter of language in its broadest conception, essentially literary studies should primarily be regarded as a special form of applied linguistics!" (ibid.).

8 Although there has lately been a renewed attention to "form" in UK literary studies, there still remains there an "uneasy complementarity" between stylistics and literary studies (Stockwell and Whiteley 3-4). In France, it seems to me that the dialogue has always been easier for historical reasons: although literary studies are becoming more context-based, they never severed the deep-rooted link between text and context. ${ }^{7}$ However, the reluctance of the literary critic regarding stylistics lies in the degree of scientificity that is allowed to be brought into the analysis of language. As it happens, here comes the linguist-witness, asking contrariwise for more scientific proof.

\subsection{Stylistics from the linguist's viewpoint}

9 The linguist's arguments against the legitimacy of stylistics could take the following forms:

1. Stylistics is too eclectic.

2. Stylistics lacks in methodology and scientific rigour.

3. Stylistics fails at bringing out generalizable results and theories. 

cylinders instead of sticking to one theory that they would develop (or criticise) in order to further its explanatory force. They thus (unfairly) borrow linguistic theories from different sources in order to suit their purpose. Moreover, they lack a clearly stated methodology that could be systematically and rigorously applied to any text. By focusing on different markers in the same text, different researchers will possibly draw different interpretations, rendering stylistic interpretation an overly subjective enterprise. Stylistics makes it rarely possible to work out theoretical generalisations from its linguistic analyses. In short, pecking at all theories without furthering any, stylistic research is fragmentary and incomplete.

cine more scientifically-oriented stylisticians in the large field of stylistics. Wishing to prove that stylistics does not lack method and is not all practice, they are striving towards one ideal: researching the most objective cause-to-effect link between the formal features that compose a text and the interpretation that can be given of them. Only plainly stated criteria based on clearly identified linguistic elements can provide the surest evaluation of a literary text. Some steps in this scientific direction have been taken by researchers like Willie van Peer in his attempt to apply a unified methodology to a variety of texts in order to come up with the most objective interpretation and evaluation. Although he concedes that readers' tastes differ and that "their concrete goals and expectations, their past reading experiences and personal biography, or their knowledge of certain genre conventions, may all drive their evaluative process in one direction or another" (van Peer, 2008 1), he still believes that the evaluation of a work of art on linguistic criteria is possible. In his formal and semantic analysis of two roughly contemporary texts with similar themes and contexts, Shakespeare's Romeo and Juliet and Arthur Brooke's The Tragicall Historye of Romeus and Juliet, he stylistically demonstrates why one of them has been positively evaluated and has entered the canon and why the other has faded into oblivion (see van Peer 1995). ${ }^{8}$ His edited book, The Quality of Literature. Linguistic Studies in Literary Evaluation (2008), is a further attempt at setting up criteria for literary evaluation beyond variations of cultures and readers, spelling out objective measures "that can be independently checked and replicated by other researchers" (ibid. 7). Falsifiability is indeed the one scientific concept that the stylistician should hold dear: truly scientific literary interpretations are interpretations that are falsifiable, which means that they can be proven false.

\subsection{Defence speech}

13 From the arguments developed just now by my fictional critical linguist, there is one that stylisticians would refuse to discuss (we're off to a good start!): the argument concerning the eclecticism of stylistics (in both choice of corpus and theories). Indeed, stylistics does not take any oath of allegiance to a particular linguistic school. Since it is not focused on the units and parts of speech that constitute the English language but on how language works and functions in context, stylistics does not believe in one and only linguistic prophet. This purposefully unfaithful attitude is a position of principle that constitutes its dynamic force (Jeffries and McIntyre 24). Freedom in the choice of theoretical tools is the one prerogative the stylistician will not relinquish. If in British 
stylistic analyses M. A. K. Halliday's systemic functional linguistics is favoured over Chomskian generative-transformational grammar, it is not regarded as embodying some superior truth that needs to be sacralised. Thus the response to argument 1 in the linguist's list would run as follows: from a stylistic angle, linguistic theories are not seen as solid rocks on which to cling but as useful tools to be tested.

Argument 3 can be dealt with right away as it seems to be an entailment of the first argument. Although stylistics does aim at drawing general theoretical conclusions from a diversity of cases, it is faced with a complex challenge. Its scale of analysis differs from that of general linguistics. Where the latter intends to draw overarching principles at the level of the whole linguistic system (of English dialects), stylistics deals with intricate phenomena that defy absolute formalisation. The metaphor of the linguistic map adopted by Jean-Jacques Lecercle $(1990,2016)$ is here useful to make visible the different scales embraced by general linguistics and stylistics: if we do need a general map of the language system, when we go down into the concreteness and complexity of phenomena, this general map is bound to be inadequate. The study of the stylistic idiosyncrasies of a text demands narrowed-down instruments of analysis. Like Mandelbrot's fractals which are too irregular to be apprehended in traditional geometrical terms, stylistic phenomena need to be approached through grammars that can only be "local." As Sinclair points out, the best linguistic theory can never be detailed and flexible enough to explain the complex relationships between form and content in literary contexts: "There was, and is, no lack of ingenious application of linguistic categories to literary works [...] but there is no theory to explain how the patterns relate to meaning [...] no detailed, comprehensive descriptive apparatus that is flexible enough to accommodate the extremely varied language of literature" (Sinclair 4). Some linguistic patterns and their textual functions cannot be explained by general grammatical categories. For example, Mahlberg ${ }^{9}(258)$ analyses structural features in an area of meaning that does not feature prominently in general grammar, that is the presentation of fictional speech (namely through the manner of speaking and body language) via a corpus analysis of patterns of words and their functions in texts. The functions are called "local" because "they do not capture general functions, but functions specific to a (group of) text(s) and/or specific to a (group of) lexical item(s)" (Mahlberg 253).

Now argument 2 is a strong claim that deserves to be addressed carefully. Stylistics aims at making explicit demonstrations based on the rigorous tracking of linguistic elements that have been defined beforehand in the most consensual manner possible. The different steps of the demonstration can be retraced by other researchers and criticized, although some may focus on other combinations of markers that seem more relevant to them. Yet, however explicit and evidenced stylistic analyses try to be, they still face methodological issues. The scientific aspirations of stylistics do need to be qualified. I do think that literary interpretations need to be more explicit than they sometimes are: a researcher should be able to state what she perceives in the text, linguistically speaking, and do so in a way that is retraceable by another analyst. It is true that some literary analyses are based on shaky linguistic descriptions out of a lack of sufficient linguistic background. However, I also maintain that the path from spotting out linguistic (ir)regularities to producing an interpretation cannot be scientifically insured. I believe Michael Toolan has come the closest to explaining why 
the falsifiability criterion needs to be used with a pinch of salt in a field of application that ultimately produces interpretations that are bound to be subjective:

If, for example, analysts agree as to what an English modal verb is by reference to various criteria (invariant in form or unmarked for tense; leftmost in the verb phrase; requiring, prior to ellipsis, an infinitive form of a lexical verb or have or be to their right; attracting negation; etc.) then a claim that the first sentence of this paragraph contains a modal verb (might) while the second does not is a falsifiable claim. But in practice, since stylistics typically involves a hermeneutic circle or spiral of grammatical description and textual interpretation, it crucially brings in commentary that is not falsifiable. (Toolan, 2014 28-9)

Because the last step will always depend on the subjective interpretation of the stylistician, no matter how explicit, evidential and systematic her argumentation is, I would tend to agree with Toolan (1990 28 and passim) that stylistics is not a "method" but a means of explaining how a crafted writer's linguistic choices manage to produce specific effects on a wide variety of readers.

Some stylistic interpretations can simply not be proven false. What best undermines the claim to falsifiability in literary stylistics is and remains the complex category of Free Indirect Speech (FIS). No matter how hard the linguist tries to establish rigorous linguistic criteria, some FIS utterances resist smooth patternings. As Monique de Mattia-Viviès shows, this is due to the fact that there are no markers of FIS per se; there are at best markers of point of view. In one of her examples (see de Mattia-Viviès 142-145, also Sorlin, 2014a 140-41), drawn from Woolf's Mrs Dalloway, "Why these people stood that damned insolence he could not conceive," the evaluative adjective "damned" indicates that the text is here situated from the character's point of view (Richard). However, there is a discrepancy between this informal adjective and the more formal semanticism of the verb "conceive." Besides de Mattia-Viviès shows that the topicalisation of the indirect interrogative clause (versus the canonical "I could not conceive why these...") is a structure that the narrator often uses when other characters are centres of conscience. Blurring the cards between narrator's verbalisation and character's attitude, this single utterance can give birth to plural interpretations that cannot all be entirely proven wrong.

The devil's advocate that I have been playing is well aware of the unfairness of the trial for all participants involved. For one thing, it presents both literature and linguistics as unified fields with homogeneous methods and positions, where what prevails in these fields, as elsewhere, is a wide diversity of approaches, tools and corpora. It also ends up harming the angel's advocate for stylistics, as it tends to present the discipline as illegitimately squeezed in between two well-established fields, struggling to conform to the constraints and prerequisites of both. The trial form gives the impression that stylistics is still at the defence stage, having nothing else to offer but defensive counterjustifications to ascertain its existence. Those days are gone. Specialists of stylistics do need to hear the critical remarks coming from its adjoining borders however-in this respect, the discipline is well guarded, with linguistics on one side correctly reminding them of their duty to rigour and literature on the other abating their scientific ambitions by highlighting the extreme malleability of language. Rather than establishing its territory on the construction of excluding borders, stylistics has paradoxically ascertained its field by removing disciplinary partitions. Part 2 will attempt to show why this constitutes its hermeneutic strength. My fictitious literary 
critic will find out along the way why some of her arguments in her plea above cannot hold for long.

\section{The creative liminality of stylistics}

\subsection{Stylistics: a welcoming field}

The eclecticism of stylistics can be construed as a weakness (see 1.2.) or a strength. The breadth of the stylistician's field is the price to pay for its openness to multiple theoretical approaches and to the diversity of its objects of study. Stylistics occupies a large path along a continuum between literary stylistics at one pole and linguistic stylistics at the other. The former is more literary-minded as it operates on the "form" of the text to come up with an interpretation of a piece of work as a whole, while the latter exploits the vast wealth of literature to further more linguistic-oriented issues. ${ }^{10}$ It is true that more literary-minded stylisticians might be less sensitive to more linguistically-oriented analyses (and vice versa) but for stylistics to remain the welcoming land it is, where dialogue can take place between different theories, this heterogeneity should be construed as an asset rather than a liability. As Jean-Michel Adam puts it, stylistics is certainly the only (remaining) place where literary people read linguistics and linguists read literature. ${ }^{11}$

The liminal place occupied by stylistics between linguistics and literature could also be seen as precious in the promotion of the more general field of what is known in France as l'anglistique. In its joint practice of both grammar and style, stylistics applies (meta)linguistic knowledge to a variety of styles from old-English texts to $21^{\text {st }}$-century literature. The literary critic (see 1.1.) may perceive the use of this wide literary corpus as disrespectful of aesthetic partitions, but I would readily retort that the more diversified the texts the students are exposed to, the more agile they become in stylistic gymnastics. By training students to read (and write in) different styles, stylistics renews with the old rhetorical tradition of imitation, that is, writing a text by adopting an author's style. This will not add up to the literary critic's interpretation of the text but it will definitely raise awareness among students of the linguistic idiosyncrasies of the text she is reading and help her understand what stylistic choices have prevailed in the writing and to what potential effects (see Sorlin, 2014a 49-51). Stylistic practice is the place where the two established academic disciplines mentioned above can shed light on one another: this is the bridging power of stylistics.

The openness of stylistics to a variety of theories and approaches is not a mere ideological stance. Theoretical and methodological choices stem from the object of study chosen by the stylistician. Depending on the question the researcher asks herself and that she wants her research to answer, the choice in corpus and ways to treat it will invariably differ. In cognitive stylistics for instance, the researcher might be interested in real readers' reactions to certain texts. Questionnaires might be the best way to go about gathering data. Stylistics does not a priori drive a wedge between practices in the humanities and in empirical science. Although one might not agree with van Peer's apprehension of the literary text (see 1.2.), one should not discard the help science can provide. Van Peer et al. (19) give the example of the evaluation of fairy tales by real readers: "Psychoanalysis holds that the semantic content of literary texts allows readers to come to terms with feelings of repressed sexuality in early childhood 
and puberty." One of van Peer's students put the claim to the scientific test by having people read fairy tales and then questioning them on whether those feelings emerged. The results showed that no readers reacted the way Freud had predicted, as van Peer $e t$ al. conclude:

What this empirical investigation shows is that Freudian theory about reading is wrong when it comes to this aspect dealing with the reading of fairy tales. It shows that the theory makes claims about reality that are obviously false when one observes how real readers go about reading. (19)

As often with scientific testing, we should be careful with the artificial reconstruction of the reading conditions and acknowledge the difficulty of obtaining truthful answers to intimate questions-besides Freudians would probably argue that "real readers" would be unaware of the psychoanalytic issues raised by fairy tales before work (between analyst and analysand) is done to elicit the said interpretations, but I cannot see why one should avoid the application of methods employed in empirical sciences, especially if they are likely to question what has always been taken for granted in the humanities. Maintaining a wall between the two cultures may be the safest way never to shake the entrenched certitudes of both fields.

23 I started this paper by mentioning that English stylistics does not enjoy the same institutional recognition as French stylistics in departments of Lettres modernes, for instance, where the discipline is present in educational competitive exams. Yet I would concur with Cécile Narjoux's conclusions about the paradoxical inventiveness of English stylistics. Although I hope stylistics takes further academic space for the reasons evoked above, it might well be at the price of some of its creativity. Institutionalisation seems to have an inevitable stifling effect for Narjoux:

Le dynamisme de la stylistique littéraire anglaise semble donc d'autant plus remarquable que, dans le cursus universitaire d'anglais de France, elle ne bénéfice pas de cours dédiées et n'est abordée que dans les cours de littérature - les études d'anglais se départageant déjà entre littérature, civilisation et linguistique, ou dans le cadre de cours de stylistique comparée adossés ou non à un cursus de traduction. Cependant, ne pourrait-on plutôt mettre en question la stylistique institutionnelle «travaillant explicitement sur des corpus relevant de valeurs indexées comme telles par la culture nationale » (Bordas) et incliner à penser que [les] « contraintes institutionnelles françaises" (Adam) amenées par l'optique des concours d'enseignement contribuent à forclore le champ de la réflexion. La liberté de penser la stylistique ne serait-elle pas justement permise par l'existence d'une réflexion en tous points excentrée, au-delà des frontières établies-géographiques, linguistiques, disciplinaires, de corpus? (11)

Do the French concours tend to format disciplines in a way that may be detrimental to their free development and influence? The question would warrant another full-length article.

It is true that English stylistics has moved off centre, instituting dialogues with other practices within the field of language study and extending the results of these dialogues to other disciplines. This is what the last section will try to evince.

\subsection{Stylistics: a migrating land}

Not only can stylistics welcome researchers of diverse linguistic and literary observance but it can also participate in other areas of knowledge. Besides literature, stylistic techniques have been exported to other fields like politics and media studies 
(Jeffries 2010, Benoît à la Guillaume 2012, Davies 2013 among others), dance and music (Vincent-Arnaud 2006, 2008). Besides, within the science of language, stylistics has a propensity to "hyphenate" with other domains of language study. This is the case in what has come to be called "pragma-stylistics," the linking hyphen testifying to a dialogue between pragmatics and stylistics, combining the two disciplines to shed light on aspects of language that used to be separated. It shows how disciplinary lines can be redrawn to liberate knowledge obstructed by disciplinary barriers. Hence the oxymoron that serves as a title to this section, stylistics being a field that does not rest content with once-and-for-all established boundaries. A short pragma-stylistic illustration is in order.

Pragma-stylistics is a relatively new field ${ }^{12}$ which takes the best of the two worlds. Pragmatics "is concerned with how language users interact, communicate and interpret linguistic behaviour" (Chapman and Clark 1) and (literary) stylistics focuses on an author's linguistic choices so as to account for how her text can be interpreted. Pragma-stylistics pays attention to the illocutionary dimension of discourse and the inferential conception of interpretation as well as the idiosyncratic linguistic choices of the speaker (in keeping with the extralinguistic conditions and context). This approach is particularly useful in the study of dialogue, whether in novels or plays, to assess how utterances are understood and how meaning is/can be inferred by the various participants. It can also be exported to another field of study which has so far neglected the linguistic aspects of dialogue: film and TV series. Dialogue in film studies has until recently been considered as "transparent", unworthy of attention, the focus being generally on the technical complexities of the editing and producing process. Film reviews sometimes comment on the language of films but often lack in scientific rigour. According to Kozloff, this neglect of discourse/language is partly explained by the fact that films were originally silent: "Film reviews fall back on vapid clichés-the dialogue is 'witty' or 'clumsy'-without specifying the grounds for such evaluations. The neglect of film dialogue by more recent film scholarship actually reflects the field's longstanding antipathy to speech in film" (6). Pragma-stylistics offers another angle of approach to this established field.

The extract below is taken from the American TV series House of Cards. Those who have seen the political series will know that Austin's performative acts are mostly infelicitous in politics as, according to the ruthless protagonist Francis Underwood, Congressmen and women cannot resist breaking promises. What is also specific about the main character in this series is his ability to play with the agentive power of language to produce diverse illocutionary and perlocutionary effects that suit his political ambitions. The pragma-stylistic study of the protagonist's linguistic choices and manipulative moves reveals the degree of power he succeeds (or not) in exerting over others (see Sorlin 2016). In this passage from season 3, President Francis Underwood tries to persuade his reluctant Democrat team to push for his big employment plan for America in the House in preparation for the 2016 presidential election:

Francis: Then let's not pretend to unite the party, let's unite the party behind this legislation.

Bob (Democratic minority leader of the House of Representatives): We'll never get it past the Republicans.

Francis: We are not here to negotiate! You want forward-thinking, Bob? Then think forward. $\uparrow$ You want a fresh face for 2016? You wanna work together? Then 
present my program to Congress. And if it dies there, so be it. But I want us to FUCKING try! $\downarrow$ I am prepared to vacate this chair. Meet me halfway. (House of Cards, Season 3, Episode 28) ${ }^{13}$ intends to create on his audience. He plays on a fall in register ("fucking") designed to produce the perlocutionary effect of surprise, jarring as it is with the civil language one commonly associates with a President of the United States. This is typical of a character in the series who does not hesitate to use the whole stylistic gamut to reach a diversity of audiences. Through a rising prosody, he offers a controlled "performance" of anger as he tries to scare his audience into compliance. Bob's reaction of surprise is nonverbal: Frank's shift in register and loud voice have the perlocutionary effect of making him sit back in his chair. The protagonist's deliberate use of a linguistic formulation that falls short of his political ethos in the short extract above must be analysed within his more general stylistic capacity to "stylise" different selves in different contexts, to take up sociolinguist Nikolas Coupland's notion of "stylisation" (2007). ${ }^{14}$ In the TV series, in enacting or performing different selves, Underwood evinces the different (false and fake) personas that politicians can assume. In so doing he attests to the force of the performative that can break free from social conventions and assume new contexts. The double approach linking stylistic and pragmatic tools of analysis can thus contribute to a more complete analysis of dialogue in TV series.

The study of style also helps to explain the audience's attraction to the series in general and the main protagonist in particular, in spite of the sundry crimes he commits. The series unconventionally breaks the fourth wall through the direct address to the viewers: the involving quality of the second person pronoun forces some form of complicity between Francis and the viewers (see Sorlin 2015). Creating a teaching relation, the direct address places the viewer in the position of the learner. In the following aside, for instance, Francis comments on his knowing his home constituents well, the better to manipulate them: "What you have to understand about my people is that they are a noble people. Humility is their form of pride. It's their strength, their weakness, and if you can humble yourself before them, they will do anything you ask" (Season 1, Episode 3). Furthermore, the semantico-syntactic structure of Underwood's asides contributes to creating an "effect of authority" that might be appealing to audience members. Devoid of doubts or hesitations, they are assertive self-confident utterances that very often take the form of proverbs: "Proximity to power deludes some into believing they wield it" (Season 1, Episode 9). Those de-subjectified aphorisms that are usually in the present tense and start with the zero article appear as indisputable arguments of authority that implicitly call for consent. What is more, Underwood's either/or rhetoric divides people and things into Manichaean exclusive categories. As he puts to death his neighbour's dog that has been run over by a car, he asserts his rhetoric of certainty: "There are two kinds of pain. The sort of pain that makes you strong, the sort of pain that's only suffering, I have no patience for useless things. Moments like this require someone who will act, who will do the unpleasant thing, the necessary thing. (He then kills the dog)" (Season 1, Episode 1). This extract is typical of Francis's strategy that consists in hoisting a local meaning/situation to a general, universal level which can hardly be contested. In the pragmatic face-to-screen game, the protagonist engages in a fake dialogue with the audience who cannot participate. The rhetorical questions he sometimes asks the viewers elicit (obvious) answers from them: "There are two types of Vice Presidents: doormats or matadors. 
Which do you think I intend to be?" (Season 2, Episode 16). Pretending to seek their complicit assent, in fact he pragma-rhetorically manipulates their critical thinking.

These extracts serve to illustrate both the potentially fruitful extensions of stylistics into other fields (i.e. pragmatics) and across other disciplinary thresholds (i.e. film/TV series studies) but also, and above all, its essential specificity that makes it an identifiable, albeit migrating, field: its irresistible attraction to language play of any kind. "If you don't like how the table is set, turn over the table," says Frank Underwood (Season 2, Episode 2). This audacious piece of advice could become the motto of stylistic practice, empowering students to play with a wide range of linguistic possibilities to achieve varied purposes and create the best effects.

\section{BIBLIOGRAPHY}

Adam, Jean-Michel. "Le continu du langage: langue et discours, grammaire et stylistique." In Cécile Narjoux (ed.), Au-delà des frontières: Perspective de la stylistique contemporaine. Bern: Peter Lang, 2012. 187-196.

Benoît à la Guillaume, Luc. Quand la Maison-Blanche prend la parole: le discours présidentiel de Nixon à Obama. Bern: Peter Lang, 2012.

Black, Elizabeth. Pragmatic Stylistics. Edinburgh: Edinburgh UP, 2005.

Burke, Michael, ed. The Routledge Handbook of Stylistics. London: Routledge, 2014.

Chapman, Siobhan and Clark, Billy, eds. Pragmatic Literary Stylistics. Basingstoke: Palgrave Macmillan, 2014.

Coupland, Nikolas. Style. Language Variation and Identity. Cambridge: Cambridge UP, 2007.

Davies, Matt. Oppositions and Ideology in News Discourse. London: Bloomsbury, 2013.

De Mattia-Viviès, Monique. Le Discours indirect libre au risque de la grammaire. Le cas de l'anglais. Aixen-Provence: Publications de l'Université de Provence, 2006.

Fowler, Robert. The Languages of Literature. London: Routledge and Kegan Paul, 1971.

Jeffries, Lesley and McIntyre, Dan. Stylistics. Cambridge: Cambridge UP, 2010.

Jeffries, Lesley. Critical Stylistics. The Power of English. Basingstoke: Palgrave Macmillan, 2010.

Hickey, Leo. "Stylistics, Pragmatics and Pragmastylistics." Revue belge de philologie et d'histoire 71.3 (1993): 573-586. DOI : 10.3406/rbph.1993.3890

House of Cards, (2013- ), Seasons 1-3, Network: Netflix. Writers: Beau Willimon, Michael Dobbs, Andrew Davies (among others). Directors: Robin Wright, David Fincher, James Foley, Joel Schumacher, Charles McDougall.

Kozloff, Sarah. Overhearing Film Dialogue. Berkeley: U. of California P., 2000.

Lecercle, Jean-Jacques. The Violence of Language. London: Routledge, 1990. 
Lecercle, Jean-Jacques, and Sandrine Sorlin. Convictions philosophiques et plaisirs linguistiques. Entretiens avec Jean-Jacques Lecercle. Toulouse: Presses Universitaires du Midi, 2016.

Mahlberg, Michaela. “Grammatical configuration.” The Cambridge Handbook of Stylistics. Ed. Peter Stockwell and Sara Whiteley. Cambridge: Cambridge UP, 2014. 249-262.

Maingueneau, Dominique. Pragmatique pour le discours littéraire. Paris: Armand Colin, 2005.

Narjoux, Cécile. "Introduction." Au-delà des frontières: Perspectives de la stylistique contemporaine. Ed. Cécile Narjoux. Frankfurt am Main: Peter Lang, 2012. 7-25.

Simpson, Paul. A Resource Book for Students. London: Routledge, 2004.

Sinclair, John. "The exploitation of meaning: literary texts and local grammars." Challenging the Boundaries. Ed. Isil Bas and Donald C. Freeman. Amsterdam: Rodopi, 2007. 1-35.

Sorlin, Sandrine. La Stylistique anglaise. Théories et Pratiques. Rennes: PUR, 2014a.

Sorlin, Sandrine. “The 'indisciplinarity' of stylistics.” Topics in Linguistics 14.1 (2014b): 9-15, DOI: 10.2478/topling-2014-0008

Sorlin, Sandrine. "Breaking the fourth wall: The pragmatics of the second person pronoun in House of Cards." The Pragmatics of Personal Pronouns. Eds. Laure Gardelle and Sandrine Sorlin. Amsterdam: John Benjamins Publishing, coll. Studies in Language Companion Series, 2015. 125-145.

Sorlin, Sandrine. Language and Manipulation in House of Cards. A Pragma-Stylistic Perspective. Basingstoke: Palgrave Macmillan, 2016.

Stockwell, Peter and Whiteley, Sara. "Introduction." The Cambridge Handbook of Stylistics. Ed. Peter Stockwell and Sara Whiteley. Cambridge: Cambridge UP, 2014. 1-9.

Stockwell, Peter and Whiteley, Sara. "Coda: the practice of stylistics." The Cambridge Handbook of Stylistics. Ed. Peter Stockwell and Sara Whiteley. Cambridge: Cambridge UP, 2014. 607-15.

Toolan, Michael. The Stylistics of Fiction. London: Routledge, 1990.

Toolan, Michael. "The theory and philosophy of stylistics." The Cambridge Handbook of Stylistics. Ed. Stockwell and Whiteley. 13-31.

Van Peer, Willie. "The historical non-triviality of art and literature. A rejoinder to Jerome Stolnitz." The British Journal of Aesthetics 35.2 (1995): 168-172. DOI: 10.1093/bjaesthetics/35.2.168

Van Peer, Willie, ed. The Quality of Literature. Linguistic Studies in Literary Evaluation. Amsterdam: John Benjamins Publishing, 2008.

Van Peer, Willie, Frank Hakemulder and Sonia Zyngier. Scientific Methods for the Humanities. Amsterdam: John Benjamins Publishing, 2012.

Vincent-Arnaud, Nathalie. "Regards sur un paysage anglais: 'Seascape,' de W. H. Auden à Benjamin Britten.” LISA e-journal IV 4 (2006): 158-169. DOI: 10.4000/lisa.1969

Vincent-Arnaud, Nathalie. “'JAZZ, baby / from every rebound' : la forme renaissante du haiku dans Jazz from the Haiku King de James A. Emanuel (1999)." Bulletin de la Société de Stylistique Anglaise 31 (2008): 33-44.

Sotirova, Violeta, ed. The Bloomsbury Companion to Stylistics. London: Continuum Publishing, 2016.

Watson, Greg and Zyngier, Sonia. Literature and Stylistics for Language Learners. Theory and Practice. Basingstoke: Palgrave Macmillan, 2007. 


\section{NOTES}

1. This is not the case in the departments of Lettres modernes in France where stylistics is represented in the CAPES. To be fair, it has started to change in the English CAPES competitive exam as linguistics is now interrelated with textual concerns brought about by translation, in the passage from English to French or vice versa.

2. See http://stylistique-anglaise.org.

3. See http://www.pala.ac.uk/.

4. See The Cambridge Handbook of Stylistics (2014), The Routledge Handbook of Stylistics (2014) and The Bloomsbury Companion to Stylistics (2016) for instance.

5. See Watson and Zyngier 2007 for an illustration of the application of stylistics to a language learning context for instance. See also Sorlin 2014a for a dialogue between grammar, style and writing.

6. This quotation and the following ones are extracted from Simpson $(2004,148-157)$ in which is replayed the "Fowler-Bateson controversy," through the reprinting of passages from R. Fowler, The Languages of Literature (1971).

7. One reason for this profound attachment to form may be found in historical pedagogical formulae adopted in the French system from the $19^{\text {th }}$ century on after Jules Ferry's educational reforms (the French explication de texte has been a prerequisite exercise in secondary and high school since that period, and is still practised all the way up to the university level today).

8. Among the stylistic differences between the two texts, the author points out the greater variety and multi-layered complexity of Shakespeare's language that presents a higher diversity of styles and registers.

9. The author gives "local grammar" a slightly different meaning from Sinclair. For Mahlberg, "the main features of a local grammar are its applicability to a specific area of the language and the emphasis on the kind of functional interpretation that addresses the negotiation of meanings in texts" (257).

10. In practice the distinction is never as decided.

11. "La stylistique est devenue le dernier espace où des littéraires lisent encore des ouvrages et des articles de linguistique et où des linguistes s'intéressent à des textes littéraires" (Adam 189).

12. See Black, Chapman \& Clark. The term has been in the air for a while though, see Hickey's 1993 definition: "Pragma-stylistics pays special attention to those features that a speaker may choose or has chosen, from a range of acceptable forms in the same language that would be semantically, or truth-conditionally, equivalent, but might perform or achieve different objectives or do so in different ways" (Hickey 578). See also Maingueneau in France.

13. The vertical arrows transcribe a rising/falling tone.

14. In Style. Language Variation and Identity, Coupland highlights the power of the individual to style-shift across diverse social situations or with different recipients and thus construct identities in talk that tend to transcend social constraints.

\section{ABSTRACTS}

Stylistics can be said to borrow tools from one well-established discipline (linguistics) and step on the disciplinary toes of another (literature). The question of the legitimacy of its borders in the academic landscape in France can deservedly be raised. In this article which questions the 
frontiers of stylistics, the author sets up a mock trial, bringing to the witness box specialists of adjacent disciplines, linguistics and literature, uncompromisingly probing the legitimacy of stylistics. After offering a defence speech, the author shows how unfair this trial is to all participants involved, the reason being that the liminal issue applies to the field of stylistics in a specific way. The perimeter of stylistic studies has not been built on the construction of exclusive borders. The author shows why the field should be construed as both a welcoming and a migrating land that must be understood in this paradox: it has gained disciplinary legitimacy by paradoxically dismantling disciplinary partitions. Stylistics is a 'connecting' discipline that can further research by reviving dialogues between distinct fields of knowledge. In a very last section, a concrete illustration is given to the bridging capacity of stylistics, as it brings new light to another discipline, film/TV series studies that have been passed over from a pragma-stylistic angle.

La stylistique anglaise emprunte les outils d'une discipline bien établie (la linguistique) tout en marchant sur les plates-bandes d'une autre (la littérature). La question de la légitimité de ses frontières dans le paysage académique français se pose donc à juste titre. Dans cet article interrogeant les bornes de la stylistique, l'auteur a recours au mode du (faux) procès qui lui permet d'amener à la barre un critique littéraire puis un linguiste questionnant sans compromis la légitimité de la discipline. Après un plaidoyer pour la cause de la stylistique, l'auteur montre en quoi ce faux procès est injuste pour l'ensemble des participants, la raison étant que la question des seuils et des frontières ne s'applique à la stylistique que d'une manière éminemment spécifique. L'auteur montre en effet pourquoi le champ de la stylistique est à la fois une terre d'accueil et de migration qui doit être appréhendée dans et par ce paradoxe : la stylistique a paradoxalement acquis sa légitimité dans le démantèlement de cloisons disciplinaires. Elle est une discipline-passerelle qui renouvelle le savoir en renouant des dialogues entre champs de savoirs séparés. L'article offre pour finir une illustration concrète de la capacité de la stylistique à éclairer un domaine jusqu'alors peu étudié d'un point de vue pragma-stylistique (les études de cinéma/séries télé).

\section{INDEX}

Keywords: legitimacy, Frontier, methodology, creativity, paradox, bridging discipline, literature, linguistics, stylistics, pragmatics, pragma-stylistics, philosophy of language, TV series

Mots-clés: légitimité, frontière, méthodologie, créativité, paradoxe, discipline-passerelle, littérature, linguistique, stylistique, pragmatique, pragma-stylistique, philosophie du langage, série télévisée

\section{AUTHOR}

\section{SANDRINE SORLIN}

Sandrine Sorlin is Professor of English language and linguistics at Aix-Marseille University and a fellow member of the Institut Universitaire de France. Specialized in stylistics and pragmatics, she has published books on linguistic defamiliarisation in English literature (La Défamiliarisation linguistique dans le roman anglais contemporain, PULM, 2010) and on language and authority in a historical perspective (Langage et autorité: de l'ordre linguistique à la force dialogique, PUR, 2012). She is also the author of a handbook of stylistics (La Stylistique anglaise. Théories et Pratiques, PUR, 2014) and the co-editor of The Pragmatics of Personal Pronouns with Laure Gardelle (John Benjamins, 2015). She has recently published a monograph on an American political TV series (Language and 
Manipulation in House of Cards: A Pragma-Stylistic Perspective, Palgrave Macmillan, 2016). She is the current chair of the Société de Stylistique Anglaise. Contact: sandrine.sorlin [at] univ-amu.fr 